\title{
IN SEARCH OF A COLOR LINE: AN EXAMINATION OF COLONIAL LAW IN VIRGINIA - CORRIGENDUM
}

\author{
Larry L. Hunt
}

doi:10.1017/S1742058X21000059, Published by Cambridge University Press, 29 March 2021.

Keywords: Constructing Race, Colonialism, Descent Groups, Legal Identities, Bonded Labor, Religion, Corrigendum

In this article (Hunt 2021) the incorrect publication by James Sweet was cited on pages 206 and 209 of the article. The correct citation (Sweet 2003) is given below. The article has since been updated.

\section{REFERENCES}

Hunt, Larry L. (2021). In Search of a Color Line: An Examination of Colonial Law in Virginia. $D u$ Bois Review: Social Science Research on Race. doi:10.1017/S1742058X21000059.

Sweet, James H. (2003). Spanish and Portuguese Influences on Racial Slavery in British North America, 1492-1619. In Collective Degradation: Slavery and the Construction of Race. Proceedings of the Fifth Annual Gilder Lehrman Center International Conference at Yale University, New Haven, CT. https://glc.yale.edu/sites/default/files/files/events/race/Sweet.pdf (accessed June 1, 2021). 